Jurnal Care Vol .5, No.3,Tahun 2017

\title{
ANALISIS FAKTOR YANG BERHUBUNGAN DENGAN EFIKASI DIRI REMAJA DALAM MELAKUKAN RESUSITASI JANTUNG PARU DI SMK NEGERI 2 SINGOSARI
}

\author{
Dudella Desnani Firman Yasin ${ }^{1)}$, Ahsan ${ }^{2)}$ Septi Dewi Racmawati ${ }^{3)}$ \\ ${ }^{1,2,3)}$ Program Studi Magister Keperawatan Peminatan Gawat Darurat \\ Fakultas Kedokteran Universitas Brawijaya Malang \\ e-mail: dudellayasin@yahoo.com
}

\begin{abstract}
Cardiac arrest is a sudden and sudden loss of cardiac function, usually occurring in someone who bas been diagnosed with beart disease or not Out-of-Hospital Cardiac Arrest (OHCA). One's confidence in doing CPR is influenced by many things. Therefore, some factors that increase self-efficacy in ordinary people are increasingly emphasized to improve RJP bystander.Purpose to analyze of factors associated with self efficacy in performing cardiopulmonary resuscitation among students of SMK Negeri 2 Singosari.This was a quantitative research with cross-sectional approach. Location of research at SMK Negeri 2 Singosari Malang. The number of respondents as many as 110 respondents taken with purposive sampling technique. Chi-square test was used to investigated the relationship between each variable and logistic regression analysis was used to identify the most dominant factor self efficacy. Chi-Square test results show $p$ value as follows experiential variable that is $p$ value $=0.007$ ( $p<0.05)$, for perceptual variables obtained $p$ value $=0.588(p>0,05$, for awareness of value $p=0,000(p<0.05)$, the knowledge obtained $p$ value $=0.663(p>0.05)$. Logistic regression test was conducted to determine the factors most related to the self-efficacy of adolescents in performing cardiopulmonary resuscitation is the awareness variable. Awareness are predictor factors that can be used to predict self efficacy, where awareness is the predominant predictor factor in affecting self-efficacy of adolescent in performing beart resuscitation at SMK Negeri 2 Singosari.
\end{abstract}

Keyword: Cardio Pulmonary Resuscitation (CPR), Adolescence, Self Efficacy, Self Efficacy Factor

\begin{abstract}
ABSTRAK
Angka kematian yang terjadi di luar rumah sakit akibat henti jantung atau Out-of-Hospital Cardiac Arrest (OHCA) menjadi salah satu fokus permasalahan kesehatan dunia karena angka kejadiannya yang tinggi dan meningkat setiap tahunnya. Penyebabnya adalah terlambatnya pelaporan dan pemberian tindakan RJP. Kepercayaan diri remaja dalam melakukan RJP dipengaruhi oleh banyak hal. Oleh karena itu beberapa faktor yang sangat penting untuk meningkatkan efikasi diri pada remaja semakin ditekankan untuk meningkatkan angka keselamatan pasien yang mengalami henti jantung di luar rumah sakit.Tujuan penelitian untuk mnganalisis faktor-faktor yang berhubungan dengan efikasi diri remaja dalam melakukan Resusitasi Jantung Paru. Desain penelitian yang digunakan adalah cross-sectional study . Lokasi penelitian di SMK Negeri 2 Singosari Malang. Jumlah sampel sebanyak 110 responden yang diambil dengan teknik purposive sampling. Analisa data menggunakan uji chi-square dan uji regresi logisitk.Hasil uji Chi-Square menunjukkan p value sebagai berikut variabel pengalaman yaitu nilai $\mathrm{p}=0,007(\mathrm{p}<0,05)$, untuk variabel persepsi didapatkan nilai $\mathrm{p}=0,588(\mathrm{p}>0,05)$,
\end{abstract}


untuk kesadaran nilai $\mathrm{p}=0,000(\mathrm{p}<0,05)$, pada pengetahuan didapatkan nilai $\mathrm{p}=0,663$ $(\mathrm{p}>0,05)$. Uji regresi logistik dilakukan untuk mengetahui faktor yang paling berhubungan dengan efikasi diri remaja dalam melakukan resusitasi jantung paru adalah variabel kesadaran Kesadaran situasional tentang henti jantung merupakan faktor prediktor yang dapat digunakan untuk memprediksi efikasi diri, dimana kesadaran merupakan faktor prediktor paling dominan dalam mempengaruhi efikasi diri remaja dalam melakukan resusitasi jantung paru di SMK Negeri 2 Singosari.

Kata Kunci: Efikasi Diri, Faktor Efikasi Diri, Remaja, Resusitasi Jantung Paru (RJP)

\section{PENDAHULUAN}

Cardiac arrest merupakan hilangnya fungsi jantung secara tiba-tiba dan mendadak, biasanya terjadi pada seseorang yang telah didiagnosa dengan penyakit jantung atau tidak. Kejadiannya berlangsung sangat cepat dan tidak bisa diperkirakan dengan menimbulkan tanda dan gejala yang tampak (American Heart Association, 2010).Out-of-Hospital Cardiac Arrest (OHCA) menjadi salah satu fokus permasalahan kesehatan dunia karena angka kejadiannya yang tinggi yaitu 50

- 60 per 100.000 orang per tahun (Berdowski et al., 2010). Tingginya angka kejadian OHCA juga diikuti dengan angka kelangsungan hidup penderita OHCA yang sangat kecil, yaitu

saja. Penyebab utama dari rendahnya survival rate korban OHCA adalah terlambatnya pelaporan dan pemberian tindakan resusitasi jantung paru (RJP) (Wnent et al., 2013).AHA (2015) merekomendasikan solusi atas masalah tersebut, yaitu dengan meningkatkan peran setiap orang di komunitas untuk menjadi seorang bystander RJP. RJP yang dilakukan dengan cepat akan meningkatkan survival rate korban OHCA sebanyak dua hingga tiga kali lipat (Hasselqvist-Ax et al., 2015). Jumlah bystander RJP di berbagai negara, terutama di negara-negara berkembang seperti di Asia Tenggara masih sedikit (Wang, Ma, \& Lu, 2015).

Resusitasi Jantung Paru harus diberikan pada korban-korban yang mengalami henti nafas, henti jantung dan perdarahan. Ketrampilan RJP ini dapat diajarkan kepada siapa saja. Setiap orang remaja atau orang dewasa seharusnya memiliki ketrampilan RJP ini (Frame, 2010). Remaja merupakan kelompok anak usia sekolah dimana memiliki rasa ingin tahu yang tinggi dan keinginan yang tinggi serta mempunyai daya ingat yang bagus. Pada masa remaja ini dapat diberikan pengetahuan tentang henti jantung dan cara penanganannya. Keengganan 
seseorang dalam melakukan RJP dipengaruhi oleh banyak hal. Oleh karena itu program pelatihan RJP pada masyarakat awam semakin ditekankan untuk meningkatkan bystander RJP yang sangat rendah. Siswa sekolah menengah atas (SMA) akan memiliki efikasi diri menjadi seorang bystander jika siswa tersebut terlatih dan siswa akan bersedia melakukan tindakan RJP pada korban OHCA (Neil et al., 2011).

Beberapa faktor yang telah diteliti yang dapat mempengaruhi orang awam untuk melakukan RJP antara lain mereka takut melakukan RJP karena merasa salah jika melakukan RJP dengan tidak benar, secara fisik tidak dapat melakukan RJP, takut merugikan individu yang ditolong, takut tertular penyakit menular, keyakinan bahwa seseorang tersebut telah meninggal. Penelitian lain juga menunjukkan bahwa pemberian ventilasi dari mulut ke mulut merupakan faktor yang paling berhubungan dalam keengganan seseorang untuk melakukan RJP terutama pada orang asing.Tujuan umum dari penelitian ini adalah untuk menganalisis faktor-faktor yang berhubungan dengan efikasi diri remaja dalam melakukan Resusitasi Jantung Paru di SMK Negeri 2 Singosari.

\section{METODE PENELITIAN}

Penelitian ini merupakan jenis penelitian kuantitatif dengan pendekatan cross sectional. Penelitian ini dilakukan di SMK Negeri 2 Singosari, Malang. Jumlah sampel sebanyak 110 yang diambil dengan teknik purposive sampling. Untuk mengetahui pengalaman, persepsi dan kesadaran digunakan instrument berupa data demografi. Untuk mengukur pengalaman tentang tindakan RJP dengan indikator yaitu berpengalaman atau tidak berpengalaman. Pengambilan data dilakukan selama satu kali. Analisa data dengan menggunakan uji Chi-Square dan untuk mengetahui faktor predictor yang paling dominan dalam hubungan efikasi diri digunakan uji regresi logistik. Kuesioner persepsi tentang tindakan RJP didapatkan beberapa indikator yang digunakan yaitu persepsi ketakutan tertular penyakit, ragu-ragu melakukan bantuan nafas dari mulut ke mulut orang awam, takut melakukan pijat jantung karena takut kondisi korban lebih buruk. Kuesioner kesadaran tentang tindakan RJP yang dimodifikasi oleh penelitian Zaheer (2009) dan Kanstad et al., (2011).

Indikator yang digunakan dalam modifikasi kuesioner kesadaran responden terhadap kejadian henti jantung, sistem gawat darurat dan 
tatalaksana RJP/Chain of survival.

Kuesioner pengetahuan tentang tindakan RJP berisi pertanyaan tertutup (Closed Ended Question) yang telah dibuat oleh kuesioner Bayu (2015). Kuesioner efikasi diri dalam melakukan tindakan RJP dikembangkan berdasarkan riset yang dilakukan oleh Howell \& Watson (2007) dan Klassen et al., (2008).

\section{HASIL}

Tabel 1 menunjukkan bahwa sebagian besar siswa SMK Negeri 2 yaitu berumur 17 tahun, mayoritas berjenis kelamin lakilaki dan hampir semuanya tidak pernah melakukan resusitasi jantung paru, dan sebagian besar mempunyai persepsi negatif serta sebagian besar mempunyai kesadaran dan pengetahuan yang rendah dalam hal resusitasi jantung paru.

Tabel 1. Distribusi Frekuensi Karakteristik Responden

\begin{tabular}{lll}
\hline $\begin{array}{l}\text { Karakteristik } \\
\text { Responden }\end{array}$ & $\mathrm{f}$ & $\%$ \\
\hline 16 tahun & 21 & 19,1 \\
17 tahun & 89 & 80,9 \\
\hline Total & 110 & 100 \\
\hline Jenis Kelamin & & \\
Laki-laki & 81 & 73,6 \\
Perempuan & 29 & 26,4 \\
\hline Total & 110 & 100 \\
\hline Pengalaman & & \\
Ya & 4 & 3,6 \\
Tidak & 106 & 96,4 \\
\hline Total & 110 & 100 \\
\hline Persepsi & & \\
Positif & 59 & 53,6 \\
negatif & 51 & 46,4 \\
\hline Total & 110 & 100 \\
\hline Kesadaran & & \\
Tinggi & 5 & 4,5 \\
Rendah & 105 & 95,5 \\
\hline Total & 110 & 100 \\
\hline Pengetahuan & & \\
Tinggi & 27 & 24,5 \\
Rendah & 83 & 75,5 \\
\hline Total & 110 & 100 \\
\hline Efikasi Diri & & \\
Tinggi & 33 & 56,5 \\
Rendah & 77 & \\
\hline Total & 110 & \\
\hline
\end{tabular}

Sumber : Data Primer (2017) 


\section{Faktor Yang Berhubungan Dengan Efikasi Diri Remaja Dalam Melakukan Resusitasi Jantung Paru}

Tabel 2. Hasil Analisis Bivariat

\begin{tabular}{lll}
\hline Variabel Independent & Variable Dependen & P value \\
\hline Pengalaman diri & Efikasi & 0,007 \\
Persepsi diri & Efikasi & 0,588 \\
Kesadaran diri & Efikasi & 0,000 \\
Pengetahuan diri & Efikasi & 0,663 \\
\hline
\end{tabular}

Sumber : Data Primer (2017)

Selanjutnya untuk mengetahui faktor yang paling dominan yang berhubungan dengan efikasi diri remaja dalam melakukan resusitasi jantung paru digunakan uji regresi logistik. Analisis multivariat dalam penelitian ini menggunakan regresi logistik karena variabel terikat (dependent) dalam penelitian ini menggunakan skala data kategorik.
Adapun syarat untuk dapat dilakukannya analisis regresi logistik pada variabel independent sebagai variabel kandidat adalah apabila nilai $\mathrm{p}$ dari masing-masing variabel tersebut pada analisis bivariat adalah $<0,25$. Analisis regresi logistik pada penelitian ini melalui empat tahapan pemodelan dengan hasil sebagai berikut:

Tabel 3. Hasil Analisis Regresi Logistik

\begin{tabular}{lccc}
\hline \multicolumn{1}{c}{ Variabel } & $\begin{array}{c}\text { Koefisien } \\
(\mathrm{B})\end{array}$ & $\begin{array}{c}\mathrm{P} \\
\text { value }\end{array}$ & OR(I 95\%) \\
\hline Langkah 1 & & & \\
Pengalaman & 0,225 & 1,000 & 1,25 \\
Kesadaran & 22,192 & 1,000 & 4,34 \\
Pengetahuan & 0,379 & 0,445 & 1,46 \\
Konstanta & $-1,281$ & 0,000 & \\
\hline Langkah 2 & & & \\
Kesadaran & 22,374 & 0,999 & 5,20 \\
Pengetahuan & 0,379 & 0,445 & 1,46 \\
Konstanta & $-1,281$ & 0,000 & 0,27 \\
\hline Langkah 3 & & & \\
Kesadaran & 22,336 & 0,000 & 5,01 \\
Pengetahuan & 0,440 & 0,819 & 1,55 \\
Konstanta & $-1,133$ & 18,452 & 0,32 \\
\hline Langkah 4 & & & \\
Kesadaran & 22,214 & 0,000 & 4,44 \\
Konstanta & $-1,012$ & 21,013 & 0,36 \\
& & & \\
\hline
\end{tabular}


Tabel 3 menunjukkan bahwa analisis Regresi Logistik pada penelitian ini melalui 4 tahapan. Pada model tahap pertama, diketahui bahwa variabel pengalaman yang memiliki nilai $\mathrm{p}=1,000(\mathrm{p}>0,05), \mathrm{OR}=$ 1,252. Hasil analisis pemodelan tahap pertama ini menunjukan bahwa variabel pengalaman memiliki nilai $\mathrm{p}$ paling besar dibandingkan dengan variabel lainnya dengan nilai OR mendekati satu. Artinya variabel tersebut harus dieliminasi dan tidak dapat diikutkan dalam analisis regresi logistik pada pemodelan tahap ke dua. Dalam analisis Regresi Logistik pada pemodelan tahap kedua variabel persepsi menunjukan nilai $\mathrm{p}$ paling besar dibandingkan variabel lainnya dan nilai OR mendekati satu, yakni $\mathrm{p}=0,552$ $(p>0,05)$ dengan $\mathrm{OR}=1,341$ dengan demikian variabel tersebut tidak dapat disertakan dalam analisis pemodelan tahap ke tiga dan harus dikeluarkan. Sedangkan variabel lainnya dapat disertakan pada analisis berikutnya. Pada analisis pemodelan tahap ke tiga dari semua variabel yang diikut sertakan, terdapat satu variabel yang harus dieliminasi dan tidak dapat dilibatkan pada analisis pemodelan tahap ke empat. Variabel yang harus dieliminasi tersebut adalah pengetahuan. Pada analisis tahap ke tiga ini variabel pengetahuan menunjukkan nilai $\mathrm{p}=0,440(\mathrm{p}>0,05)$ dimana nilai tersebut merupakan nilai $\mathrm{p}$ paling besar dibandingkan dengan variabel lainnya dengan $\mathrm{OR}=1,553$. Hasil analisis pemodelan pada tahap ke empat menunjukan bahwa terdapat 1 variabel yang berhubungan dengan efikasi diri remaja dalam melakukan resusitasi jantung paru di SMK Negeri 2 Singosari. Kekuatan hubungan dari masing-masing variabel tersebut dapat dilihat dari nilai $\operatorname{OR}(\operatorname{EXP}\{\mathrm{B}\})$. Berdasarkan hasil tersebut dapat disimpulkan bahwa remaja yang memiliki memiliki kesadaran yang tinggi untuk melakukan resusitasi jantung paru kemungkinan 4,443 kali lebih besar untuk memiliki efikasi diri yang tinggi dibandingkan dengan mereka yang memiliki kesadaran rendah dalam hal resusitasi jantung paru tentu saja setelah dikontrol dengan variabel persepsi, dan pengetahuan.

\section{PEMBAHASAN}

\section{Hubungan Pengalaman dengan Efikasi Diri Remaja Dalam Melakukan Resusitasi Jantung Paru}

Hasil analisis dapat diinterpretasikan bahwa nilai signifikansi yang diperoleh untuk variabel pengalaman adalah 0,007 . Oleh karena nilai signifikansi $\mathrm{p}<0.05$, maka $H_{1}$ diterima sehingga secara garis besar ada hubungan antara pengalaman dengan efikasi diri remaja dalam 
melakukan resusitasi jantung paru di SMK Negeri 2 Singosari. Hasil penelitan diatas sesuai dengan penelitian yang dilakukan oleh Bobo (2012) yang menyatakan bahwa 27 siswa menyatakan kemampuan meningkat secara siginifikan pada siswa tahun kedua dan junior, sedangkan pada mahasiswa pasca sarjana menunjukkan peningkatan efikasi diri yang tinggi. Hal ini dikarenakan efikasi diri dipengaruhi oleh persepsi tentang kemampuan individu melakukan tugas yang menantang dimana kinerja seseorang atau ketrampilan seseorang akan meningkatkan kemanjuran diri siswa di berbagai klasifikasi akademik. Peserta dinilai dapat melakukan ketrampilan klinis psikomotorik mobilisasi setelah diberikan intervensi sebuah videovideo terkait pelatihan. Setelah intervensi didapatkan hasil secara signifikan pada siswa kelas dua dan yunior. Klasifikasi akademis sangat berpengaruh terhadap efikasi diri siswa. Semua kelompok megalami peningkatan efikasi diri dan didapatkan korelasi positif pada kelompok intervensi dimana awalnya efikasi diri rendah tetapi setelah diberikan intervensi didapatkan efikasi diri tinggi. Hasil ini berkebalikan dengan penelitain yang dilakukan oleh Gonzi (2015) yang menyatakan bahwa meskipun seseorang mempunyai pengalaman tetapi tidak menunjukkan hubungan antara pengalaman dengan efikasi diri remaja. Tidak ada korelasi yang signifikan antara pengalaman dengan efikasi diri remaja setelah diberikan sebuah simulasi mengenai resusitasi jantung paru. Seseorang yang memiliki efikasi diri yang tinggi mampu melakukan RJP dengan baik meskipun memiliki kompetensi yang rendah. Hal tersebut didukung oleh penelitian yang dilakukan oleh Wagler (2011) yang menyatakan bahwa tidak ada korelasi antara pengalaman dengan efikasi diri seseorang dimana telah dialakukan penelitian pada 46 individu yang berpengalaman dalam hal RJP.

\section{Hubungan Persepsi dengan Efikasi}

\section{Diri Remaja Dalam Melakukan}

\section{Resusitasi Jantung Paru}

Berdasarkan hasil penelitian nilai signifikansi yang diperoleh untuk variabel persepsi adalah 0.588 . Oleh karena nilai signifikansi lebih besar dari taraf signifikansi $5 \% \quad(p=0.588>0.05)$, maka dapat dinyatakan bahwa H1 ditolak sehingga tidak terdapat hubungan antara persepsi dengan efikasi diri remaja dalam melakukan resusitasi jantung paru di SMK Negeri 2 Singosari. Hasil ini sesuai dengan penelitian yang dilakukan oleh Drosten (2016) pada penelitian yang dilakukan terhadap 8522 responden didapatkan hasil bahwa responden dengan persepsi negatif 
tidak secara signifikan mempengaruhi efikasi diri terhadap orang awam yang akan melakukan RJP. Hal ini dikarenakan orang awam tersebut takut melakukan bantuan nafas melalui mulut ke mulut serta orang awam takut melakukan bantuan resusitasi jantung paru dikarenakan takut akan tindak pidana hukum ketika akan melakukan RJP. Penelitian lain yang mendukung penelitian tersebut telah dilakukan oleh (James 2014) yang menyatakan bahwa tidak terdapat korelasi bivariat yang signifikan antara persepsi dengan efikasi diri pada remaja. Berdasarkan hasil penelitian yang telah dilakukan di SMK Negeri 2 Singosari bahwa persepsi tidak berhubungan dengan efikasi diri remaja dalam melakukan resusitasi jantung paru.

\section{Hubungan Kesadaran dengan Efikasi}

\section{Diri Remaja Dalam Melakukan}

\section{Resusitasi Jantung Paru}

Hasil analisis menunjukkan bahwa nilai signifikansi yang diperoleh untuk variabel kesadaran adalah 0,000 . Oleh karena nilai signifikansi lebih kecil dari taraf signifikansi $5 \% \quad(\mathrm{p}=0.000<0.05)$, maka dapat dinyatakan bahwa $\mathrm{H}_{1}$ diterima sehingga terdapat hubungan antara kesadaran tentang henti jantung dengan efikasi diri remaja dalam melakukan resusitasi jantung paru di SMK Negeri 2 Singosari. Sebuah kesadaran yang dimiliki oleh seseorang pada sebuah situasi, suatu pemahaman dinamis tentang akan apa yang sedang terjadi merupakan pengertian dari kesadaran terhadap situasi. Pengertian lain menjelaskan bahwa yang paling sering digunakan dari kesadaran situasi adalah apa yang ditawarkan menjelaskan sebuah hasil dari produk yaitu pengkajian situasi (Endsley, 1995a, p.36). Berbagai cara dijelaskan untuk mengembangkan kesadaran diri dapat dilakukan dengan cara menganalisis diri dan merefleksikan diri melalui pikiran dan perasaan. Motivasi, pola pikir, pola tindakan dan pola interaksi dalam berhubungan dengan orang lain merupakan salah satu cara untuk menganalisis dan merefleksikan diri. Suatu kondisi, kepribadian dan karakter atau temperamen diri yang lebih stabil dengan orang lain juga merupakan salah satu cara untuk menganalisis hal tersebut. Cara seseorang untuk merespon terhadap stimulus dari objek luar yang menyenangkan atau tidak menyenangkan merupakan definisi dari sikap.

Hasil penelitian ini sesuai dengan penelitian Berg et al (2010) yang menyatakan bahwa kesadaran mengenai telpon Emergency Medical Service (EMS) menjadi suatu hal yang sangat penting bagi 
remaja terlebih lagi ketika ada sebuah kejadian henti jantung. Ketika remaja sadar akan kejadian henti jantung maka efikasi diri akan timbul pada saat kesadaran muncul. Remaja akan memanfaatkan layanan EMS ini untuk membantu mengurangi korban henti jantung. Waktu yang sangat berharga pada korban yang mengalami henti jantung merupakan akibat dari gagalnya aktivasi 'Emergency response system' atau untuk melakukan tindakan RJP dengan segera. Pengenalan adanya kasus henti jantung dan pertolongan secara dini menjadi hal yang sangat penting untuk dilakukan yang terdapat dari banyak guidline. Seorang relawan ketika mengenali adanya korban yang tidak sadarkan diri di tempat kejadian maka relawan tersebut harus cepat menyuruh orang lain untuk mengaktivasi suatu sistem kegawatdaruratan yang ada. Penolong harus segera melakukan prosedur RJP setelah adanya aktivasi. Hal ini didukung oleh penelitan Suharsono dan Kartikawati (2009) yang menyatakan bahwa pengenalan tanda awal henti jantung sangat penting untuk disadari oleh setiap individu karena henti jantung merupakan kejadian yang penting dimana sifatnya mengancam nyawa seseorang. Apabila korban pada kasus henti jantung tidak mendapatkan penanganan dengan segera maka kematian akan terjadi dalam hitungan menit saja pada korban. Penelitian lain juga menyebutkan bahwa terlambatnya pengenalan tanda dan gejala yang terjadi pada korban henti jantung merupakan penyebab gagalnya usaha pertolongan terhadap korban henti jantung. Situasi atau keadaan dimana korban tidak sadarkan diri atau tanpa adanya pernafasan bahkan adanya pernafasan tidak normal merupakan gejala utama yang harus dikenali dan diketahui oleh masyarakat awam secara dini serangan henti jantung. Salah satu cara termuda untuk mengenali atau menilai respon korban adalah dengan cara menepuk bahu korban dan menanyakan keadaannya (Supriyono, 2008).

Kesadaran pada seorang siswa didapatkan dalam sebuah pembelajaran yang memungkinkan dimana pembelajaran mengenai korban henti jantung dapat meningkatkan kesadaran untuk tanggap terhadap kejadian henti jantung. Dimana pembelajaran harus bersifat dua arah yang tidak berfokus pada materi atau instruksi saja tetapi kepada kondisi yang lebih aktif Baker et al., 2005). Proses mengolah informasi tersebut untuk menjadi suatu makna yang sangat logis merupakan suatu proses kesadaran yang dibutuhkan yaitu dengan tersampaikannya informasi secara tepat dan bermakna. Penelitan yang 
dilakukan oleh TzuFen su (2014) menyatakan bahwa kepercayaan diri atau efikasi diri individu berhubungan dengan kesadaran dimana telah dibuktikan pada penelitian selama 2 semester pada siswa SMA dan didapatkan hasil bahwa dengan menggunakan educational game card siswa dapat belajar dengan baik sehingga ketika ada kejadian henti jantung maka efikasi diri pada siswa meningkat serta kesadaran yang menyebabkan efikasi diri meningkat pada individu tersebut.

\section{Hubungan Pengetahuan dengan Efikasi Diri Remaja Dalam}

\section{Melakukan Resusitasi Jantung Paru}

Hasil analisis menunjukkan bahwa nilai signifikansi yang diperoleh untuk variabel pengetahuan adalah 0,663 . Oleh karena nilai signifikansi lebih besar dari taraf signifikansi $5 \% \quad(\mathrm{p}=0.663>0.05)$, maka dapat dinyatakan bahwa $\mathrm{H}_{1}$ diterima sehingga tidak terdapat hubungan antara pengetahuan dengan efikasi diri remaja dalam melakukan resusitasi jantung paru di SMK Negeri 2 Singosari. Hasil ini berkebalikan dengan penelitian yang dilakukan oleh Afrianto pengetahuan dapat mempengaruhi efikasi diri dimana setelah diberikan pengajaran terhadap keselamatan efikasi diri meningkat. Penelitian ini sejalan dengan penelitian Gutierrez di Filipina (2013) dimana terdapat pengaruh antara pengetahuan dengan efikasi diri setelah mendapatkan pembelajaran menggunakan kartu. Pengetahuan meningkat dan dapat memahami konsep yang telah diajarkan, dengan meningkatnya pengetahuan maka efikasi diri remaja juga meningkat.

Kasus henti jantung merupakan suatu hal fenomena dimana kasus henti jantung tidak dapat ditemui secara regular dan pengetahuan tentang tatalakasana Resusitasi Jantung Paru (RJP) bukan merupakan sesuatu hal yang mudah untuk dipahami dan dimengerti serta tidak mudah dikerjakan ketika belum mengerti. Kecepatan memberikan bantuan pertolongan berpengaruh pada keselamatan hidup korban. Sehingga pengetahuan dan kemampuan melakukan RJP harus ada ketika dibutuhkan dengan segera serta teknik RJP harus lebih ditekankan pada setiap orang awam khususnya pada remaja. RJP membutuhkan baik pengetahuan dan kemampuan motorik karena RJP merupakan suatu pelatihan yang cukup sulit. Pengetahuan tentang RJP dapat memberikan dampak ketahanan yang lama daripada ketrampilan RJP karena dengan pengetahuan yang cukup mengenai RJP maka dapat mempengaruhi efikasi diri untuk melakukan RJP pada korban yang 
mengalami henti jantung (Lynch et al., 2005).

Penatalaksanaan segera pada korban yang diduga mengalami henti cjantung menggunakan Chain of Survival dimana hal ini sangat penting dilakukan untuk menyelamatkan nyawa seorang korban henti jantung. Untuk mengoptimalkan harapan hidup seseorang maka harus dilakukan sesuai dengan Chain of Survival dimana seorang harus dikenalkan terhadap pengenalan dan akses segera ke pelayanan gawat darurat segera setelah melakukan RJP dan untuk mendapatkan perawatan lebih lanjut merupakan suatu kesatuan dalam memaksimalkan harapan hidup seorang korban henti jantung.

Angka keselamatan (survival rate) dapat mendekati 50\% pada kasus henti jantung apabila rantai keselamatan ini dapat dilakukan dengan efektif yang ditolong oleh relawan RJP dengan gambaran Ventricular fibrillation (VF). Peningkatan pengetahuan masyarakat tentang konsep Chain of Survival sangat penting dilakukan untuk mengoptimalkan penanganan korban henti jantung yang terjadi dimanapun berada (Berg et al., 2010).

\section{Faktor yang Paling Dominan Berhubungan Dengan Efikasi Diri Remaja Dalam Melakukan Resusitasi Jantung Paru}

Berdasarkan analisis regresi logistik yang menggunakan metode backward LR didapatkan hasil akhir bahwa variabel yang paling berhubungan dengan efikasi diri remaja adalah variabel kesadaran. Kesadaran merupakan faktor dominan yang berhubungan dengan efikasi diri remaja dalam melakukan resusitasi jantung paru di SMK Negeri 2 Singosari. Hal ini ditunjukkan oleh penelitian yang dilakukan oleh Young et al (2011) di Korea menyatakan bahwa kesadaran remaja tentang keadaan henti jantung merupakan faktor dominan karena kesadaran bukan hanya pada petugas pelayanan kesehatan saja tetapi juga pada masyarakat luas atau bystander RJP yang sangat penting berhubungan dengan pertolongan awal yang cepat pada korban yang mengalami henti jantung. Maka secepatnya orang awam/ bystander semakin cepat menyelamatkan korban henti jantung dengan menelepon ambulans EMS.

Hasil penelitian ini sesuai dengan penelitian Berg et al (2010) yang menyatakan bahwa kesadaran mengenai telpon Emergency Medical Service (EMS) menjadi suatu hal yang sangat penting bagi 
masyarakat terlebih lagi ketika ada sebuah kejadian henti jantung. Ketika masyarakat sadar akan kejadian henti jantung maka efikasi diri akan timbul pada saat kesadaran muncul. Waktu yang sangat berharga pada korban yang mengalami henti jantung merupakan akibat dari gagalnya aktivasi 'Emergency response system' atau untuk melakukan tindakan RJP dengan segera. Pengenalan adanya kasus henti jantung dan pertolongan secara dini menjadi hal yang sangat penting untuk dilakukan yang terdapat dari banyak guidline. Seorang relawan ketika mengenali adanya korban yang tidak sadarkan diri di tempat kejadian maka relawan tersebut harus cepat menyuruh orang lain untuk mengaktivasi suatu sistem kegawatdaruratan yang ada. Penolong harus segera melakukan prosedur RJP setelah adanya aktivasi. Hal ini didukung oleh penelitan Suharsono dan Kartikawati (2009) yang menyatakan bahwa pengenalan tanda awal henti jantung sangat penting untuk disadari oleh setiap individu karena kejadian henti jantung merupakan kejadian yang penting dimana sifatnya mengancam nyawa seseorang. Apabila korban pada kasus henti jantung tidak mendapatkan penanganan dengan segera maka kematian akan terjadi dalam hitungan menit saja pada korban. Penelitian lain juga menyebutkan bahwa terlambatnya pengenalan tanda dan gejala yang terjadi pada korban henti jantung merupakan penyebab gagalnya usaha pertolongan terhadap korban henti jantung. Situasi atau keadaan dimana korban tidak sadarkan diri atau tanpa adanya pernafasan bahkan adanya pernafasan tidak normal merupakan gejala utama yang harus dikenali dan diketahui oleh masyarakat awam secara dini serangan henti jantung. Salah satu cara termuda untuk mengenali atau menilai respon korban adalah dengan cara menepuk bahu korban dan menanyakan keadaannya (Supriyono, 2008).

\section{KESIMPULAN}

Kesadaran dapat digunakan untuk memprediksi efikasi diri, dimana kesadaran situasional henti jantung merupakan faktor prediktor yang paling dominan berhubungan dengan efikasi diri remaja dalam melakukan resusitasi jantung paru di SMK Negeri 2 Singosari. Faktor ini merupakan faktor dominan atau prediktor untuk efikasi diri remaja dalam melakukan resusitasi jantung paru.

\section{SARAN}

Hasil penelitian ini dapat dijadikan data dasar dalam menyusun perencanaan program pembelajaran hard skill dan soft skill penatalaksanaan henti jantung dalam 
melaksanakan resusitasi jantung paru pada korban yang mengalami serangan jantung. Diperlukan penelitian lebih lanjut terkait hubungan proses pengambilan keputusan dengan efikasi diri remaja dalam melakukan resusitasi jantung paru. Untuk penelitian selanjutnya diharapkan dapat menggali lebih dalam terkait pengetahuan remaja dalam melakukan resusitasi jantung paru dan menggali lebih mendalam terkait persepsi orang awam atau remaja dalam melakukan resusitasi jantung paru pada korban yang mengalami henti jantung.

\section{REFERENSI}

American Heart Association CPR and First Aid. (2015). About Cardiopulmonary Resuscitation (CPR). Ann Intern Med. 157. p: 1928.

Ann Britt.(2007). How Can We Optimize By Stander Basic Life Support in Cardiac Arrest?. Institute of Medicine Dept. of Molecular and Clinical Medicine/Cardiology Sahlgrenska Academy at Göteborgs University Sahlgrenska University Hospita Göteborg, Sweden

Badan Penelitian dan Pengembangan Kesehatan Kementrian Kesehatan RI.(2013).Riset Kesehatan Dasar (Riskesdas 2013), Kementrian
Kesehatan Republik Indonesia, Jakarta

Baker A,Oh Navarro E, van $\operatorname{derHoekA.~}$ (2005). An experimental card game for teaching software engineering processes. J Syst Software 75, 3-16.

Baskett P, Nolan J, Parr M. (1996). Tidal Volumes Which are Perceived to be Adequate for Resuscitation. Resuscitation; 31(3): 231-4.

Becker LB, Berg RA, Pepe PE. (1997). A reappraisal of mouth-tomouth ventilation during bystander-initiated cardiopulmonary resuscitation: A Statement for Healthcare Professionals From the Ventilation Working Group of the Basic Life Support and Pediatric Life Support Subcommittees, American Heart Association. Ann Emerg Med 30:654-66.

Berg, Robert A, Chair, Robin Hemphill.(2010). Part 5 : Adult Basic Life support: American Heart Association Guidlines for Cardiopulmonary Ressucitation and Emergency Cardiovascular Care. Circulation. 2010;122:S685S705

Bryan,M., Rachel R., Monica M., Kimberly. (2011). Out-of-hospital Cardiac Arrest Surveillance Cardiac Arrest Registry to 
Enhance Survival (CARES), United States. Morbidity and Mortality Weekly Report Surveillance Summaries. Vol. 60 / No. 8.

Christensona,J.(2009). The Effect of Time on CPR and Automated External Deibrilator Skills in the Public Acces Defibrilation Trial. Ressucitation : 74, 52-63

Gutierrez, Arnel F. (2013). Development and Effectiveness of an Educational Card Game as Supplementary Material in Understanding Selected Topics in Biology. Education Department, Bulacan State UniversitySarmiento Campus, City of San Jose del Monte, Bulacan 3023, Philippines

Kamus Besar Bahas Indonesia (KBBI). (2007).

Kanstad SK, Nielsen SA, Fredikesen K. (2011). CPR Knowledge and Attitude to Performing by Stander CPR Among Secondary School Students in Norway. Resuscitation 82 (2011) 1053- 1059. Elsevier Ireland Ltd
SOS-KANTO.(2007). Study Group. Cardiopulmonary resuscitation by bystanders with chest compression only (SOS-KANTO): an observational study. Lancet; 369:920-6.

Suharsono, T dan Kartikawati, D. (2009). Penatalaksanaan Henti Jantung di Luar Rumah Sakit. UMM Press : Malang.

Supriyono, Mamat.(2008). Faktor-Faktor Risiko Yang Berpengaruh Terbadap Kejadian Penyakit Jantung Koroner. UNDIP : Semarang.

TzuFen su, Meng-Tzu Cheng, and ShuHua Lin. (2014). Investigating the Effectiveness of an Educational Card Game for Learning How Human Immunology Is Regulated. Department of Biology, National Changhua University of Education, Changhua 500, Taiwan.

Zaheer, Hasan. (2009). Awareness About BLS (CPR) Among Medical Students: Status and Requirements. J Pak Med Assoc : Vol. 59, No. 1, January 2009 